\title{
INFLUENCE OF MARKETING MANAGEMENT PRACTICUM AT KOPINMART UNPAM AGAINST STUDENT INTEREST BECOME ENTREPRENEURS
}

\author{
Afrida Yani ${ }^{1}$, Lyandra Aisyah Margie ${ }^{2}$, Habibah $^{3}$ \\ Prodi Akuntansi S1, Fakultas Ekonomi, Universitas Pamulang \\ afridayanirayyan@gmail.com
}

\begin{abstract}
The purpose of this study was to determine the effect of marketing management practicum on student interest to become entrepreneurs in accounting students at UNPAM (Universitas Pamulang). This study uses a simple linear regression analysis technique. The analysis was performed using SPSS software version 24.0. The population in this study amounted to 361 active S1 Accounting Economics students who have received marketing management practicum subjects in the even semester 2018-2019, while samples taken incidentally were 118 students. The results of the research that have been done show that the marketing management practicum has a significant effect on student's interest to become entrepreneurs through Kopinmart UNPAM. This proves that the existence of special subjects namely marketing management practicum and the provision of facilities to Kopinmart UNPAM products can make students more confident and have a high motivation to become an entrepreneur.
\end{abstract}

Keywords: Marketing management practicum, interest become entrepreneurs.

\section{INTRODUCTION}

Education is a central point for realizing human resources that are able to adapt to all their ages. Because education is a conscious and planned effort to create an atmosphere of learning and learning process so that students actively develop their potential to have spiritual spiritual strength, self-control, personality, intelligence, noble character, and the skills needed by themselves, the nation's people and the Indonesian state (Hidayat, Friska, Anggraini, Syafi'i \& Kusumaningsih, 2019).

One of the driving and supporting factors in a country to create a business in society is the university. Higher education has a significant role in creating entrepreneurship for students, which will have an impact on the proliferation of educated small businesses in communities that build from scratch.

One of the efforts made by the University of Pamulang, faculty of economics, especially the accounting program to reduce unemployment, is the implementation of marketing and entrepreneurial management practices. UNPAM has prepared and 
pioneered students by providing soft skills and after graduating from college can open jobs.

The concept of practicum-based learning practice is learning that uses teaching and learning strategies by practicing. Practicum is a teaching system that is directly related to practice and direct observation so that a learning strategy by adding knowledge and understanding of objects or facts that are needed.

Practicum is a very important part in education, especially entrepreneurship education. The practice will automatically be realized if there is a variety of support, one of which is a facility. The statement provides a condition that in marketing management education is not enough by learning theory, but must be accompanied by practice. Practice is a way to carry out in reality what is stated in theory.

The concept of entrepreneur is as a process, namely the process of creating something new (new creation) and making something different from existing ones or innovations. An entrepreneur or entrepreneur is a person who sees an opportunity then establishes an organization to take advantage of the opportunity.

The intention of entrepreneurship reflects one's commitment to starting a new business and is a central issue that needs to be considered in understanding the entrepreneurship process of establishing a new business. Entrepreneurs as the spirit, ability, attitude, behavior of natural individuals handle businesses or activities that lead to efforts to find, create, implement work methods, technology and new products by increasing efficiency in order to provide better services to obtain greater profits.

\section{THEORETICAL FRAMEWORK AND HYPOTHESIS}

\subsection{Marketing Management}

Marketing management is the analysis, planning, implementation and control of programs designed to create, build and maintain mutually beneficial exchanges with target buyers in order to achieve organizational goals. That process involves more than just getting enough customers for the company's current output. More than just designing strategies to attract new customers and create transactions with them, companies now focus on retaining current customers and building long-term relationships through offering superior value and satisfaction to customers. Marketing seeks to attract consumers by promising superior value and retaining old customers by providing satisfaction. Kotler (2007) states, marketing is a business function that identifies wants and needs that have not been met now and measures how large the market will be served, determine which target markets are best served by organizations, and determine the right products, services and programs for serving that market.

\subsubsection{Interest}

Interest is a situation where someone has attention to something and is accompanied by a desire to know and learn or further prove Walgito (1981: 38). In 
learning, a concentration is needed so that what is learned can be understood. So students can do something that previously could not be done.

Interest can be interpreted as "a high tendency towards something, interest, attention, passion and desire". Another opinion about the notion of interest that is expressed by T. Albertus, translated by Sardiman A.M, interest is "A person's awareness that an object, a person, a problem or situation that has something to do with himself" (2006: 32). According to Hilgard quoted by Slamet (2003: 57) interest is "a constant tendency to pay attention and remember some activities". Activities that are of interest to someone are given constant attention and are accompanied by feelings of pleasure.

\subsubsection{Entrepreneurship}

The word Entrepreneur comes from the French, entreprendre, which has been known since the 17th century, which means trying. In terms of business, the intention is to start a business. The Merriam-Webster Dictionary describes the definition of an entrepreneur as someone who organizes and bears the risk of a business or business.

According to Zimmerer (2008) Entrepreneurship is the application of creativity and innovation to solve problems and efforts to take advantage of opportunities faced by people every day.

Entrepreneurship is a combination of creativity, innovation and courage to face the risks carried out by working hard to form and maintain new businesses. From the view of experts it can be concluded that Entrepreneurship is the ability to think creatively and behave in an innovative manner which is used as a basis, resources, driving force, tactics, tips and processes in facing life's challenges.

\section{RESEARCH METHOD}

This research will be carried out within approximately six months from the signing of the research agreement. As the location of research at the University of Pamulang, J1. Surya Kencana 1 Pamulang, Banten.

\subsection{Data Collection Techniques}

The technique used in sampling in this study is non-probability sampling, which is a sampling technique that does not provide equal opportunities for each element or member of the population to be selected as a sample (Sugiyono, 2008: 120). The non-probability method chosen for use in this study is convenience sampling, which is a sampling technique based on convenience. Where researchers take samples by chance which are then considered to match the characteristics of the specified samples (Noor, 2015: 155).

\subsection{Operational Definitions of Variables}

The data obtained by researchers in this study are of two types namely data sourced from primary data that is the first data source at the research location or research object. Respondents in this study were accounting students at the University of Pamulang. And secondary data is the second source of data needed. 
In this case the secondary data source is documentation related to university profiles and student data.

\subsection{Sample Collection Techniques}

The data collection techniques used in this study are questionnaires which in this study will be applied with questions that will lead respondents to answer questions according to the actual reality. As well as documentation to find out information about research subjects to be examined.

\subsection{Data Analysis Techniques}

This study uses a simple linear regression analysis technique, because there are two variables involved in this research, namely marketing management practicum as an independent variable and symbolized by $X$ and student interest in becoming entrepreneurs as the dependent variable and denoted by Y.

The simple linear regression analysis was performed using SPSS software version 24.0.

\section{DATA ANALYSIS AND DISCUSSION}

This research was conducted at Pamulang University with the population in this study amounting to 361 undergraduate students in active accounting economics who had received marketing management practicum courses in the even semester 2018-2019, while samples taken incidental (incidental sampling) were 118 students.

\subsection{Data Analysis}

Respondents in this study were students who had received marketing management practicum courses. The description of the general description of respondents in this study based on the results of a questionnaire that has been collected regarding the characteristics of respondents by gender can be seen as the follows:

Table 4.1 : Description of Respondents

\begin{tabular}{|c|c|c|}
\hline \multicolumn{3}{|c|}{ Gender } \\
\hline Information & Amount & Percentage \\
\hline Man & 37 & $31 \%$ \\
\hline Woman & 81 & $69 \%$ \\
\hline Total & 118 & $100 \%$ \\
\hline
\end{tabular}

Source : Self Proceed

Based on table 1 above, it can be seen that the majority of respondents were female, amounting to 81 respondents or $69 \%$, while male respondents amounted to 37 respondents or as much as $31 \%$.

\section{Validity Test}


Validity Test is used to measure the validity of a questionnaire. The test is done using bivariate correlation, the guideline of a model is said to be valid if the value of $r$ count is greater than the value of $r$ table at $\alpha=5 \%$ (Hidayat, 2020). The $r$ table value in this study was obtained from the degree of freedom (df) formula with 118 samples pre-test $(\mathrm{df}=118-2=116$, meaning the 116th df table is 0.1809).

The validity test results show that the marketing management practicum variables and students' interest to become entrepreneurs have valid criteria for all question items based on $r$ count criteria greater than $r$ tables of 0,1809 .

\section{Reliability Test}

Reliability is actually a tool to measure a questionnaire which is an indicator of a variable or construct. A questionnaire is said to be reliable or reliable if someone's answer to the statement is consistent or stable from time to time (Ghozali, 2013: 47). SPSS provides facilities to measure reliability with Cronbach Alpha $(\alpha)$ statistical tests. A construct or variable is said to be reliable if it gives a Cronbach Alpha value > 0.70 (Ghozali, 2013: 48).

Cronbach's Alpha coefficient calculations are performed using SPSS software version 24.0. The following are the results of the reliability test of the marketing management practicum variables and the interest of students to become entrepreneurs:

Table 4.2 Reliability Test

\begin{tabular}{|c|c|c|c|}
\hline Variable & Cronbach's Alpha & N of Items & Description \\
\hline X1 & 0,914 & 31 & Reliable \\
\hline
\end{tabular}

\section{Source : Self Proceed}

Table 4.2 shows the value of Cronbach's alpha on marketing management practicum variables and the interest of students to become entrepreneurs by 0.914 . Thus, it can be concluded that the questions in this questionnaire are reliable because they have a Cronbach's alpha value greater than 0.70 .

\section{Normality Test}

The purpose of the normality test is to test whether in the regression model, independent variables, dependent variables, or both have normal distribution or not. (Ghozali, 2011: 161). In this study to test the normality of the data used the Kolmogorov-Smirnov one-sample test as follows:

Table 4.3 : Normality Test

One-Sample Kolmogorov-Smirnov Test

Unstandardized

Residual

\begin{tabular}{ll}
\hline $\mathrm{N}$ & 118 \\
\hline
\end{tabular}




\begin{tabular}{llr}
\hline Normal Parameters & Mean &, 0000000 \\
\cline { 2 - 3 } Most Extreme Differences & Std. Deviation & 4,99100387 \\
\cline { 2 - 3 } & Absolute &, 049 \\
\cline { 2 - 3 } & Positive &, 049 \\
\cline { 2 - 3 } & Negative &,- 042 \\
\hline Test Statistic & &, 049 \\
\hline Asymp. Sig. (2-tailed) & &, $200^{\mathrm{c}, \mathrm{d}}$ \\
\hline
\end{tabular}
a. Test distribution is Normal.
b. Calculated from data.
c. Lilliefors Significance Correction.
d. This is a lower bound of the true significance.

\section{Source : Self Proceed}

Based on table 4.3 above it is known that the significance value of 0.200 is greater than 0.05 so it can be concluded that the tested data are normally distributed.

To test whether or not the data distribution is normal can also be done by looking at a normal probability plot graph comparing the cumulative distribution of the normal distribution (Ghozali, 2011: 162). From the results of the normal p-plot graphic data that has been done it can also be seen that the data distribution is centered on the average value and the media or p-plot value is located on a diagonal line, so it can be said that the data of this study have a normal distribution and distribution.

\section{Determination Coefficient Test}

The coefficient of determination (Adjusted R Square) basically measures how far the model's ability to explain variations in the dependent variable. In the SPSS output, the coefficient of determination lies in the model table and is written $\mathrm{R}$ square (Ghozali, 2011: 97).

\section{Table 4.4 : Determination Coefficient Test}

\begin{tabular}{|c|c|c|c|c|}
\hline \multicolumn{5}{|c|}{ Model Summary } \\
\hline Model & $\mathrm{R}$ & R Square & $\begin{array}{c}\text { Adjusted R } \\
\text { Square } \\
\end{array}$ & $\begin{array}{c}\text { Std. Error of the } \\
\text { Estimate }\end{array}$ \\
\hline 1 &, $718^{\mathrm{a}}$ & ,516 & ,511 & 5,012 \\
\hline
\end{tabular}

Table 4.4 above shows the value of $\mathrm{R}$ Square of 0.516 or $51.6 \%$. This shows that the variable of student interest in becoming an entrepreneur that can be influenced by the marketing management practicum variable is $51.6 \%$. While the remaining 0.484 or $48.4 \%$ is influenced by other variables.

\section{Simple Linear Regression}

To see the magnitude of the effect of marketing management practicum at Kopinmart UNPAM on the interest of students becoming entrepreneurs partially 
used the $t$ test. If the value of $t$ arithmetic $>t$ table, it can be concluded that the independent variable has a partial effect on the dependent variable. If the value of $t$ count $<t$ table, it can be concluded that the independent variable has no effect on the dependent variable partially. Then if the probability value $t$ is smaller than the error level $\alpha=0.05$, it can be said that the independent variable significantly influences the dependent variable. Whereas if the probability value of $t$ is greater than the error level $\alpha=0.05$, it can be said that the independent variable does not significantly influence the dependent variable. The results of the $t$ test calculations from this study are as follows:

\section{Table 4.5 : Simple Linear Regression Analysis}

\begin{tabular}{|c|c|c|c|c|c|c|}
\hline \multicolumn{7}{|c|}{ Coefficients $\mathrm{s}^{\mathrm{a}}$} \\
\hline & & \multicolumn{2}{|c|}{$\begin{array}{l}\text { Unstandardized } \\
\text { Coefficients }\end{array}$} & \multirow{2}{*}{$\begin{array}{c}\text { Standardized } \\
\text { Coefficients } \\
\text { Beta } \\
\end{array}$} & \multirow[b]{2}{*}{$\mathrm{t}$} & \multirow[b]{2}{*}{ Sig. } \\
\hline \multicolumn{2}{|c|}{ Model } & B & Std. Error & & & \\
\hline \multirow[t]{2}{*}{1} & (Constant) & 16,792 & 4,639 & & 3,620 &, 000 \\
\hline & $\begin{array}{l}\text { Praktikum } \\
\text { Manajemen } \\
\text { Pemasaran }\end{array}$ & ,847 & ,076 & ,718 & 11,113 & ,000 \\
\hline
\end{tabular}

a. Dependent Variable: Minat Berwirausaha

\section{Source : Self Proceed}

Based on table 4.5 above, the partial test results show the t-count of marketing management practicum variables (X) is 11.113 while the t-table with $\alpha=5 \%$ and $\mathrm{df}=(\mathrm{nk})$ is $\mathrm{df}=(118-1)=117$, then $\mathrm{t}$-table $(0.05 ; 117)=1.65787$ so that $\mathrm{t}$-count $>$ t-table (11.113> 1.65787), it can be concluded that the independent variable marketing management practicum $(\mathrm{X})$ influences the dependent variable of student interest to become entrepreneurs (Y). Then the probability value sig. advertising $<0.05(0.000<0.05)$, it can be said that there is a significant influence of the marketing management practicum variable $(\mathrm{X})$ on the variable of student interest in becoming an entrepreneur (Y).

A constant of 16.792, implies that the consistent value of the participation variable is 16.792 . While the regression coefficient $X$ of 0.847 states that every 1 increase in the value of practicum in marketing management, the value of student interest in becoming entrepreneurs increases by 0.847 . The regression coefficient is positive, so it can be said that the direction of the effect of variable $\mathrm{X}$ on $\mathrm{Y}$ is positive.

The results of this study are almost in line with research by Asmawan (2017) who found that after participating in entrepreneurial practices organized by study programs, students generally have growing courage and confidence, assured and strong to enter the world of entrepreneurship.

Munir (2015, in Asmawan, 2017) states that one of the factors that motivates students to become entrepreneurs is a university policy that supports student motivation in entrepreneurship. This is in line with what has been implemented by the Faculty of Economics, University of Pamulang which strongly supports 
entrepreneurial student programs.

This is evidenced by the existence of special subjects namely marketing management practicum and the provision of facilities to students to market Kopinmart UNPAM products. The results obtained after they carry out this activity also prove that students are increasingly confident and have high motivation to become an entrepreneur.

\subsection{Discussion}

The results of this study are almost in line with research by Asmawan (2017) who found that after participating in entrepreneurial practices organized by study programs, students generally have growing courage and confidence, assured and strong to enter the world of entrepreneurship.

Munir (2015, in Asmawan, 2017) states that one of the factors that motivates students to become entrepreneurs is a university policy that supports student motivation in entrepreneurship. This is in line with what has been implemented by the Faculty of Economics, University of Pamulang which strongly supports entrepreneurial student programs.

This is evidenced by the existence of special subjects namely marketing management practicum and the provision of facilities to students to market Kopinmart UNPAM products. The results obtained after they carry out this activity also prove that students are increasingly confident and have high motivation to become an entrepreneur.

\section{CONCLUSION}

Based on the results of research that has been done, it can be concluded that the marketing management practicum has a significant effect on the interests of students to become an entrepreneurs through Kopinmart UNPAM. The purpose of marketing management practicum conducted by the Faculty of Economics is to provide knowledge, attitudes and skills to students so that they become students who have an entrepreneurial spirit. Through this practice students are expected to be able to take advantage of existing opportunities to market Kopinmart UNPAM products so that students have direct experience in entrepreneurship without only knowing their theories. After attending a marketing management practicum conducted by the Economy Faculty of UNPAM, students have the courage and strong confidence to start a business. Effectively, students show their pleasure in doing a business and further demonstrate their motivation to keep it.

\section{REFERENCES}

Alma, Buchari. (2004). Kewirausahaan. Bandung: Alfabeta

Amirullah dan Haris Budiyono. (2004). Pengantar Manajemen. Yogyakarta: Graha Ilmu

Asmawan. Moh. Chairil. (2017). Dampak Mata Kuliah Praktek Kewirausahaan 
Terhadap Motivasi Mahasiswa Pendidikan Akuntansi Untuk Berwirausaha. Seminar Nasional Pendidikan 2017 (SNP 2017), ISSN: 2503-4855

Firdaus, Vera dan Hisbiyatul Hasanah. (2018). Pengaruh Pelatihan dan Pendidikan Kewirausahaan Terhadap Motivasi Berwirausaha Pada Penyandang Disabilitas di Kabupaten Jember. FENOMENA Vol. 17 No 2 Oktober 2018

Ghozali, Imam. (2013). Aplikasi Analisis Multivariate dengan Program SPSS Edisi Ketujuh. Semarang: Badan Penerbit Universitas Diponegoro.

Hidayat, A. (2020). Pengaruh penggunaan aplikasi eviews terhadap kemampuan pemecahan masalah dan hasil belajar statistik. MAJU: Jurnal Ilmiah Pendidikan Matematika, 7(1), 18-24.

Hidayat, A., Friska, Y., Anggraini, A., Syafi'i, M. T., \& Kusumaningsih, A. (2019). Peningkatan Keterampilan Dasar Matematika dan Bahasa Inggris Sebagai Upaya dalam Menghadapi Tantangan Era Revolusi Industri 5.0. Abdimisi, 1(1), 55-62.

Hendro. (2011). Dasar - Dasar Kewirausahaan. Jakarta: Erlangga

Kotler, Phillip. (2007). Manajemen Pemasaran, Jilid 2, Edisi 12. New Jersey: PT. Indeks.

Maulandy Rizky Bayu Kencana. (2018, 7 Desember). Mau Jadi Negara Maju, Indonesia Harus Punya Banyak Wirausahawan. Retrieved from https://www.liputan6.com/bisnis/read/3801780/mau-jadi-negara-majuindonesia-harus-punya-banyak-wirausahawan

Miflen, Fj dan Miflen, Fc. (2003). Simply-Psychology. Jakarta: Raja Grafindo Pustaka

Slameto. (2003). Belajar dan Faktor-Faktor yang Mempengaruhinya. Jakarta: Rineka Cipta.

Sugiyono. (2008). Metode Penelitian Kuantitatif, Kualitatif dan R\&D. Bandung: Alfabeta

Suryabrata, Sumadi. (2006). Metodologi Penelitian. Jakarta: PT. Raja Grafindo Persada

UU Nomor 20 Tahun 2003. Sistem Pendidikan Nasional. Pasal 1 Ayat 1.

Walgito, Bimo. (1981). Pengantar Psikologi Umum. Yogyakarta: Fakultas Psikologi UGM.

Zimmerer, Thomas W. (2008). Kewirausahaan dan Manajemen Usaha Kecil. Jakarta: Salemba Empat. 